\title{
Note on the texts
}

Citations from Spenser's works are from A.C. Hamilton's edition of The Faerie Queene and from the Yale Shorter Poems edited by William A. Oram et al. For citations from Donne's works, this volume adheres to contributors' individual preferences as to the edition. The use of unmodernised or modernised spellings, except in the Index, follows these editions. 
Yulia Ryzhik - 9781526117366 Downloaded from manchesterhive.com at 04/26/2023 11:16:47AM via free access 